\title{
Chemical aspects of peracetic acid based wastewater disinfection
}

\author{
Tero Luukkonen ${ }^{1 *}$, Juhani Teeriniemi', Hanna Prokkola' ${ }^{1}$, Jaakko Rämö² and Ulla Lassi'1,3 \\ 'University of Oulu, Department of Chemistry, Fl-90014, University of Oulu, Finland \\ ${ }^{2}$ University of Oulu, Thule institute, Fl-90014 University of Oulu, Finland \\ ${ }^{3}$ Kokkola University Consortium Chydenius, Unit of Applied Chemistry, Talonpojankatu 2B, Fl-67100 Kokkola, Finland
}

\begin{abstract}
Peracetic acid (PAA) has been studied for wastewater disinfection applications for some 30 years and has been shown to be an effective disinfectant against many indicator microbes, including bacteria, viruses, and protozoa. One of the key advantages compared to, e.g., chlorine is the lack of harmful disinfection by-products. In this paper a pilot-scale study of PAAbased disinfection is presented. Indicator microbes (E. coli, total coliforms and coliphage viruses) as well as chemical parameters $(\mathrm{pH}$, oxidation-reduction potential (ORP), chemical and biochemical oxygen demand (COD and $\mathrm{BOD})$, and residual PAA and hydrogen peroxide) were studied. The main aim of this investigation was to study how these selected chemical parameters change during PAA treatment. Based on the results, disinfection was efficient at C.t values of 15 to 30 (mg.min)/ $/ \ell$ which equals to a PAA dose of 1.5 to $2 \mathrm{mg} / \ell$ and a contact time of 10 to $15 \mathrm{~min}$. In this concentration area changes in $\mathrm{pH}$, $\mathrm{COD}$ and $\mathrm{BOD}$ were negligible. However, hydrogen peroxide residues may interfere with COD measurements and apparent COD can be higher than the calculated theoretical oxygen demand (ThOD). Additionally PAA or hydrogen peroxide residues interfere with the BOD test resulting in BOD values that are too low. Residual PAA and ORP were found to correlate with remaining amounts of bacteria.
\end{abstract}

Keywords: tertiary wastewater disinfection, peracetic acid, total coliform, E. coli, coliphages

\section{INTRODUCTION}

Wastewater treatment has traditionally focused on the removal of solids, organic material and nutrients (phosphorus and more recently nitrogen). Additionally, microbes in wastewater are typically removed up to about $98 \%$ in a conventional treatment process without disinfection (Tchobanoglous et al., 2004). Remaining pathogens are often thought to diminish via dilution in natural waters or to be inactivated by stress factors such as $\mathrm{pH}$, temperature, salinity, nutrient availability, and oxidative stress (Rozen and Belkin, 2001). However, this is not always sufficient if there are activities taking place which involve the receiving water body, such as bathing, fishing or fish farming for example. Globally, microbiological quality of wastewater is becoming ever more important due to the water scarcity in many areas and therefore the need to recycle or reuse treated wastewater is now considerably higher than before.

There are many alternative techniques for wastewater disinfection that can be used individually or in combination: chlorine compounds (gas and hypochlorite), chlorine dioxide, ultraviolet (UV) radiation, ozone, and peracetic acid (PAA). Chlorine is still globally the most common disinfectant due to its low cost, however the awareness of harmful by-products and the formation of chlorination-resistant bacteria strains causes wastewater plants to consider other options. Recently performic acid (PFA) has also been proposed as a wastewater disinfectant but additional research is necessary as there are currently no published results about, e.g., by-product formation and toxicity effects (Gehr et al., 2009).

To whom all correspondence should be addressed. 욜 +35 844 535-3695; e-mail: tero.luukkonen@oulu.fi Received 4 February 2013; accepted in revised form 6 December 2013.
The role of PAA in wastewater disinfection has been extensively studied since the early 1980s and PAA has also been used as a disinfectant for many years in the food, beverage, and paper industries (Orth, 1998; Rasimus et al., 2011). PAA is commercially available as a stabilised equilibrium mixture containing PAA (typically 5 to $15 \% \mathrm{w} / \mathrm{w}$ ), hydrogen peroxide, acetic acid, and water (Eq. (1)). PAA is considered to be the main active component in the solution (Baldry, 1983; Baldry and French, 1989; Fraser et al., 1985; Kitis, 2004; Lubello et al., 2002).

$$
\mathrm{CH}_{3} \mathrm{COOOH}(\mathrm{aq})+\mathrm{H}_{2} \mathrm{O}(\mathrm{l}) \leftrightarrow \mathrm{CH}_{3} \mathrm{COOH}(\mathrm{aq})+\mathrm{H}_{2} \mathrm{O}_{2}(\mathrm{aq})
$$

The disinfection efficiency of PAA in wastewater applications has been demonstrated numerous times in the literature (Antonelli et al., 2006; Baldry, 1983; Baldry and French, 1989; Baldry et al., 1991; Baldry et al., 1995; Briancesco et al., 2005; Collivignarelli et al., 2000; Dell'Erba et al., 2004; Gehr et al., 2003; Kitis, 2004; Koivunen and Heinonen-Tanski, 2005a; Koivunen and Heinonen-Tanski, 2005b; Lefevre et al., 1992; Liberti and Notarnicola, 1999; Liberti et al., 1999; Salgot et al., 2002; Veschetti et al., 2003; Zanetti et al., 2007). As a result, $\mathrm{PAA}$ is gaining acceptance as a disinfectant, especially in the United Kingdom and Italy (Falsanisi et al., 2006). Examples of full-scale installations include Milan Nosedo wastewater treatment plant (WWTP) in Italy and Mikkeli Kenkävero WWTP in Finland.

A recent study by Azzellino et al. (2011) showed that PAA disinfection is more dependent on dosage than on contact time. This indicates that the traditional C.t (dose amount $\mathrm{x}$ contact time) concept may need a weighting coefficient for the $t$ term. Additionally, PAA seems to possess faster inactivation kinetics for E. coli compared to total coliform bacteria (TCB), which was also confirmed by Mezzanotte et al. (2007). These findings are important in terms of selecting a representative indicator microbe and interpreting disinfection test results. 


\begin{tabular}{|c|c|c|}
\hline \multicolumn{3}{|c|}{$\begin{array}{c}\text { TABLE } 1 \\
\text { Effects of wastewater characteristics on the disinfection efficiency of peracetic acid }\end{array}$} \\
\hline $\begin{array}{l}\text { Wastewater } \\
\text { characteristic }\end{array}$ & Effect & Reference \\
\hline Temperature & Disinfection efficiency increases with temperature. Active between 0 and $100^{\circ} \mathrm{C}$. & $\begin{array}{l}\text { Baldry et al. (1995); } \\
\text { Stampi et al. (2001) }\end{array}$ \\
\hline $\mathrm{pH}$ & $\begin{array}{l}\text { More effective in acidic conditions. Above } \mathrm{pH} 9 \text { the efficiency starts to decrease. } \\
\text { The non-dissociated form }\left(\mathrm{CH}_{3} \mathrm{COOOH}\right) \text { is thought to be a more active disinfect- } \\
\text { ant than the dissociated form }\left(\mathrm{CH}_{3} \mathrm{COOO}\right) \text {. }\end{array}$ & Kitis (2004) \\
\hline $\begin{array}{l}\text { Suspended solids, } \\
\text { turbidity }\end{array}$ & $\begin{array}{l}\text { Slight decrease in the disinfection efficiency as suspended solids or turbidity } \\
\text { increases. This can be seen in the required dose for different effluents: } \\
\text { primary }>\text { secondary > tertiary. }\end{array}$ & $\begin{array}{l}\text { Koivunen and Heinonen- } \\
\text { Tanski (2005b); Lefevre } \\
\text { et al. (1992) }\end{array}$ \\
\hline Organic matter & $\begin{array}{l}\text { High organic load may increase the required dose, however it is less affected than } \\
\text { other chemical disinfection methods. No significant formation of harmful by- } \\
\text { products in reactions with organic matter. }\end{array}$ & $\begin{array}{l}\text { Koivunen and Heinonen- } \\
\text { Tanski (2005b) }\end{array}$ \\
\hline Transition metals & $\begin{array}{l}\text { Catalytic decomposition and radical formation by PAA and hydrogen peroxide can } \\
\text { be initiated by transition metals. In the case of the radical mechanism, disinfection } \\
\text { activity may intensify. }\end{array}$ & $\begin{array}{l}\text { Zhao et al. (2008); } \\
\text { Rothbart et al. (2012) }\end{array}$ \\
\hline $\begin{array}{l}\text { Bicarbonate, } \\
\text { chloride }\end{array}$ & May cause abatement of radicals (e.g. $\mathrm{OH} \bullet$ ) by radical scavenging effects. & $\begin{array}{l}\text { Gultekin and Ince } \\
\text { (2004); Liao et al. (2001) }\end{array}$ \\
\hline
\end{tabular}

Although PAA has been shown to be relatively insensitive towards suspended solids (Koivunen and Heinonen-Tanski, 2005b; Lefevre et al., 1992) or organic materials (Koivunen and Heinonen-Tanski, 2005b), in wastewater it seems reasonable to apply PAA disinfection to effluents that are as well-processed as possible. General effects of wastewater chemical and physical characteristics on disinfection with PAA are shown in Table 1. The best results can be expected when treating filtered tertiary effluents, i.e., applying the so-called multiple barrier concept (Liberti and Notarnicola, 1999). Large and heavy parasites (e.g. helminth eggs) are removed by filtration and smaller pathogens such as viruses and bacteria are destroyed by disinfection. However, De Velásquez et al. (2008) showed recently that PAA, per se, is effective against helminth eggs, although relatively high doses are needed.

Additional hygienic safety can be achieved by combining UV and PAA, which can be classified as an advanced oxidation process (AOP) (Lubello et al., 2002; Koivunen and HeinonenTanski, 2005a; Caretti and Lubello, 2003; Rajala-Mustonen et al., 1997). This UV/PAA synergy is based on an enhanced formation of radicals (e.g., hydroxyl radicals, $\mathrm{OH} \bullet$ ), which makes the conditions very unfavourable to microbes as the two techniques complement each other (Bianchini et al., 2002). Another way to improve disinfection efficiency is the addition of copper or silver ions with PAA (De Velásquez et al., 2008; Luna-Pabello et al., 2009).

Disinfection by-product (DBP) formation during PAA disinfection has been studied by Dell'Erba et al. (2007), who found that no brominated or chlorinated phenols are formed. While some formation of aldehydes did occur, PAA tends to further oxidise them to carboxylic acids and eventually to carbon dioxide. They also stressed that the amount of formed aldehydes never exceeded the Italian maximum allowable concentrations. Another study was performed by Crebelli et al. (2005) who used bacterial mutagenicity and plant genotoxicity tests to assess the formation of harmful DBPs. Their results using 2 to $4 \mathrm{mg} / \ell$ of PAA and a contact time of 26 to $37 \mathrm{~min}$ in secondary settled effluent suggested that no formation of genotoxic DBPs took place. Similar results were also obtained by Monarca et al. (2002).

In this paper PAA was used to disinfect tertiary municipal wastewater effluent within a pilot scale set-up. The following chemical parameters were monitored before and after the disinfection process: chemical oxygen demand $\left(\mathrm{COD}_{\mathrm{Cr}}\right)$, biochemical oxygen demand $\left(\mathrm{BOD}_{7, \mathrm{ATU}}\right), \mathrm{pH}$, oxidation-reduction potential (ORP) and, finally, residual PAA and hydrogen peroxide concentrations. Disinfection efficiency was assessed by monitoring the following indicator microorganisms: coliform bacteria (E. coli and total) and coliphage viruses (F-specific and somatic). The purpose of this study was to clarify how selected chemical parameters change during PAA disinfection.

\section{EXPERIMENTAL}

\section{Experimental set-up}

Disinfection tests were performed at Oulu WWTP in Taskila, Finland. The pilot plant consisted of a circular contact basin in which tertiary effluent from the full-scale WWTP was fed by using a submersible pump (Fig. 1). Mixing of the PAA chemical and wastewater was performed by a set-up involving an overflow weir. Contact time in the basin was adjustable by controlling the inlet valve and was tested using food dye. PAA was added to the water entering the contact basin with the aid of a diaphragm pump.

\section{Characteristics of tertiary effluent before disinfection}

The process employed at Taskila's WWTP process consists of pre-treatment (screening and aerated sand separation), primary treatment (polyaluminium chloride dosing, mixing, seasonal flocculating polymer dosing, and sedimentation), secondary treatment (activated sludge process with denitrification and nitrification stages, ferric sulphate and seasonal flocculating polymer dosing, and sedimentation), and tertiary treatment (sand filtration). Tertiary sand filters are used for the removal of solids and denitrification whilst methanol feeding to sand filters is used as an additional carbon source. The main characteristics of the tertiary effluent are shown in Table 2.

\section{Chemicals and methods}

ORP (oxidation reduction potential) and $\mathrm{pH}$ were measured 


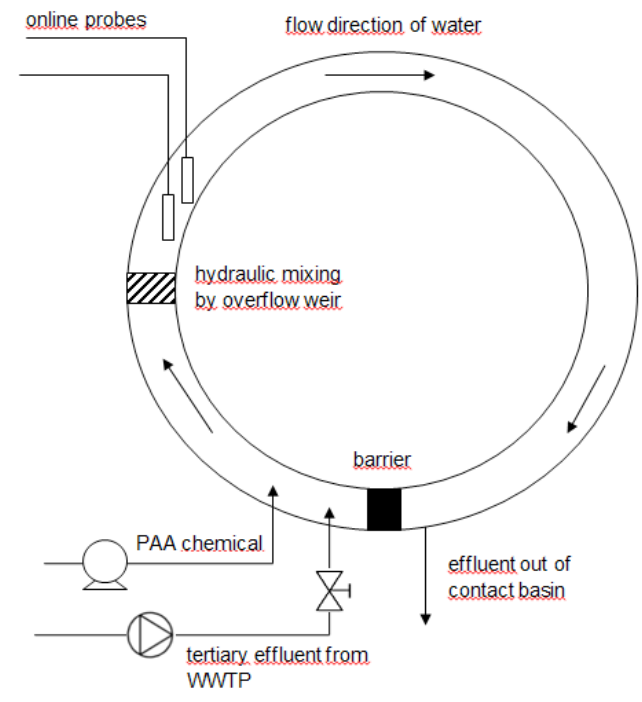

Figure 1

Schematic diagram of the experimental set-up used in the study as seen from overhead

with a multiparameter probe (Ezodo 7300) in situ at the pilot plant. The ORP probe consisted of a platinum test electrode together with a reference $\mathrm{Ag} / \mathrm{AgCl}$ electrode.

Chemical oxygen demand $\left(\mathrm{COD}_{\mathrm{Cr}}\right)$ was measured with a Hach Lange DR 2800 photometer using Hach Lange cuvette tests which employed the closed reflux dichromate method. Biochemical oxygen demand with allylthiourea (ATU) addition and a measurement time of 7 days $\left(\mathrm{BOD}_{7, \text { atu }}\right)$ was determined using the OxiTop manometric respirometric method under OECD 301F standard conditions.

Residual PAA and hydrogen peroxide concentrations were measured using a Chemetrics V2000 photometer and cuvette tests (K-7913 for PAA and modified K-5543 for $\mathrm{H}_{2} \mathrm{O}_{2}$ ). The K-5543 cuvette test method for $\mathrm{H}_{2} \mathrm{O}_{2}$ measurements was modified by adding 5 drops of approximately $11 \%$ potassium iodide solution (Chemetrics) to each sample before testing to remove the possible interference caused by PAA.

Samples used for E. coli, TCB, and coliphage virus analysis were collected in sterile PET bottles. Sodium thiosulphate solution (FF-chemicals) was then added to the samples to quench the residual PAA $(9 \mathrm{~g} / \ell$ solution with $1 \mu \ell$ to $1 \mathrm{~m} \ell$ sample dosing). TCB and E. coli were analysed according to the Finnish standard method SFS 3016:2001 whilst coliphage viruses were analysed according to EPA Method 1602 using a dual or single layer agar technique. Hosts used were $E$. coli CN-13 (ATCC\#700609) and E. coli $\mathrm{F}_{\text {amp }}$ (ATCC\#700891), for somatic and $\mathrm{F}$ specific coliphages, respectively. Coliphage virus analyses were performed at the National Institute for Health and Welfare of Finland.

Finally, the PAA chemical used in the study was PACS12 (Solvay) which contained 12\% (w/w) PAA, 20\% hydrogen peroxide and $20 \%$ acetic acid.

\section{RESULTS AND DISCUSSION}

\section{Effect of PAA doses on the ORP and $\mathrm{pH}$}

The results of ORP measurements at different PAA doses are shown in Fig. 2. For comparison, changes in ORP in primary settled effluent are also shown. The initial ORP of tertiary
TABLE 2

Main characteristics of tertiary effluent from Taskila (Oulu) WWTP

\begin{tabular}{|l|c|c|c|}
\hline Parameter & Min value & $\begin{array}{c}\text { Max } \\
\text { value }\end{array}$ & $\begin{array}{c}\text { Mean } \\
\text { value }\end{array}$ \\
\hline Temperature $\left({ }^{\circ} \mathrm{C}\right)$ & 6.8 & 7.0 & 6.9 \\
\hline $\mathrm{ORP}_{\text {with respect to } \mathrm{Ag} / \mathrm{AgCl}(\mathrm{mV})}$ & 10.2 & 12.2 & 11.3 \\
\hline $\mathrm{COD}_{\mathrm{Cr}}\left(\mathrm{mg} / \ell \mathrm{O}_{2}\right)$ & 100 & 190 & 150 \\
\hline $\mathrm{BOD}_{\mathrm{z}_{\text {atu }}\left(\mathrm{mg} / \ell \mathrm{O}_{2}\right)}$ & 7 & 52 & 16 \\
\hline Total coliform bacteria $(\mathrm{CFU} / 100 \mathrm{~m} \ell)$ & 4000 & 160000 & 50867 \\
\hline E. coli $(\mathrm{CFU} / 100 \mathrm{~m} \ell)$ & 3900 & 90000 & 24025 \\
\hline Somatic coliphages $(\mathrm{PFU} / 100 \mathrm{~m} \ell)$ & 170 & 4400 & 1800 \\
\hline F specific coliphages $(\mathrm{PFU} / 100 \mathrm{~m} \ell)$ & 40 & 800 & 420 \\
\hline
\end{tabular}

$C F U=$ colony forming unit, $P F U=$ plague forming unit

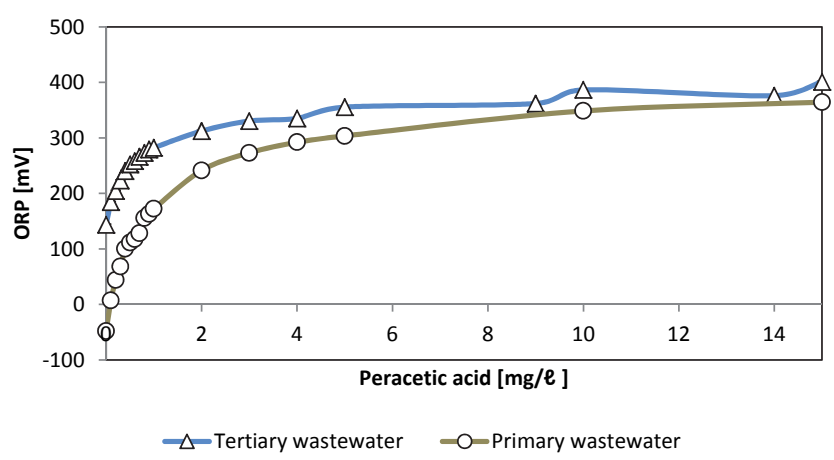

Figure 2

ORP with respect to $\mathrm{Ag} / \mathrm{AgCl}$ electrode as a function of peracetic acid concentration in primary and tertiary effluent

effluent (an average of about $150 \mathrm{mV}$ ) indicates a generally oxidative situation and the presence of free oxygen (Goncharuk et al., 2010). ORP changes quite steeply in the concentration area of 0.1 to $1.0 \mathrm{mg} / \ell$ PAA whereas higher levels of PAA concentration only result in a slight increase in the ORP. A similar trend also applies to primary effluent. An increase in ORP is in part related to the decomposition of PAA and hydrogen peroxide and subsequent release of dissolved oxygen. At higher doses, the effluent quickly becomes saturated with oxygen and therefore the rate of increase in ORP settles down.

There are numerous publications available about the applications of ORP in water and wastewater disinfection, especially with chlorination (Kim and Hensley, 1997; Bergendahl and Stevens, 2005; Yu and Cheng, 2003). Bergendahl and Stevens (2005) showed that when ORP is greater than $650 \mathrm{mV}$, it ensures bacterial inactivation against E. coli, Salmonella or Pseudomonas, which is in agreement with WHO guidelines for keeping ORP at $700 \mathrm{mV}$ during the disinfection of drinking water (Goncharuk et al., 2010). In addition, Kim and Hensley (1997) showed that ORP correlates better than chlorine residual with residual coliform bacteria. We conducted a similar test with PAA and our results (Fig. 3) showed that a linear correlation between residual PAA and TCB or E. coli values is slightly better (correlation coefficients being -0.975 and -0.934 , respectively) than for ORP and total coliform amounts (correlation coefficients being -0.948 and -0.829 , respectively). Both ORP and residual PAA can be monitored online for modulating the chemical feed. As with chlorine-based disinfection (Kim and Hensley, 1997), these parameters can be used for the 

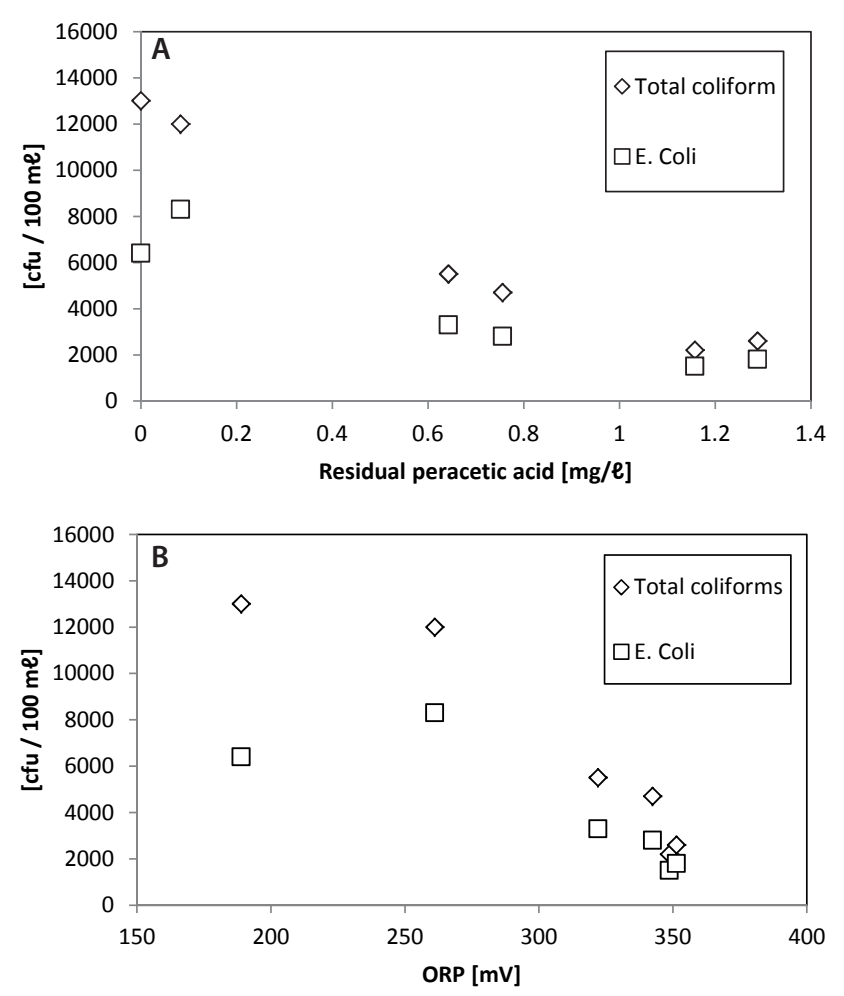

Figure 3

Correlation between the amounts of total coliform bacteria or $\mathrm{E}$. coli and (A) residual PAA concentration and (B) ORP. Residual PAA, ORP and bacterial amounts were measured after a contact time of $1 \mathrm{~min}$.

optimisation of chemical consumption. However, it may be necessary to determine the correlation of bacterial amounts and ORP in each WWTP site individually.

Changes in $\mathrm{pH}$ were plotted against dosed PAA $(\mathrm{mg} / \ell)$ resulting in a linear fit with $R^{2}=0.854$ :

$$
\mathrm{pH} \text { change }=-0,033 * \text { dosed PAA }(\mathrm{mg} / \ell)
$$

As municipal wastewaters are generally well buffered against $\mathrm{pH}$ changes by bicarbonates, only relatively small decreases in $\mathrm{pH}$ take place per each added $\mathrm{mg} / \ell$ of PAA. Koivunen and Heinonen-Tanski (2005b) reported that $7 \mathrm{mg} / \ell$ of PAA dose decreased the $\mathrm{pH}$ by 0.24 and $0.18 \mathrm{pH}$ units in secondary and tertiary wastewater, respectively. These numbers are consistent with our results.

\section{Chemical and biochemical oxygen demand}

Changes in $\mathrm{BOD}_{7, \text { atu }}, \mathrm{COD}_{\mathrm{Cr}}$, and theoretical oxygen demand (ThOD) at different PAA concentrations are shown in Fig. 4. ThOD was calculated by assuming that all PAA reacts to acetic acid and then is oxidised completely according to Eq. (3).

$$
\mathrm{CH}_{3} \mathrm{COOH}(\mathrm{aq})+2 \mathrm{O}_{2}(\mathrm{aq}) \rightarrow 2 \mathrm{CO}_{2}(\mathrm{~g})+2 \mathrm{H}_{2} \mathrm{O}(\mathrm{l})
$$

Changes in ThOD depend on the composition of the used PAA chemical (i.e. the ratio of PAA to conjugate acetic acid). In this particular case the addition of $1 \mathrm{mg} / \ell$ of PAA increases COD about $4.0 \mathrm{mg} / \ell \mathrm{O}_{2}$. For comparison, Kitis (2004) calculated a $2.8 \mathrm{mg} / \ell \mathrm{O}_{2}$ increase in COD for the addition of $1 \mathrm{mg} / \ell$ of PAA.

COD follows the ThOD curve quite closely; however, there are several measurements showing significantly higher COD

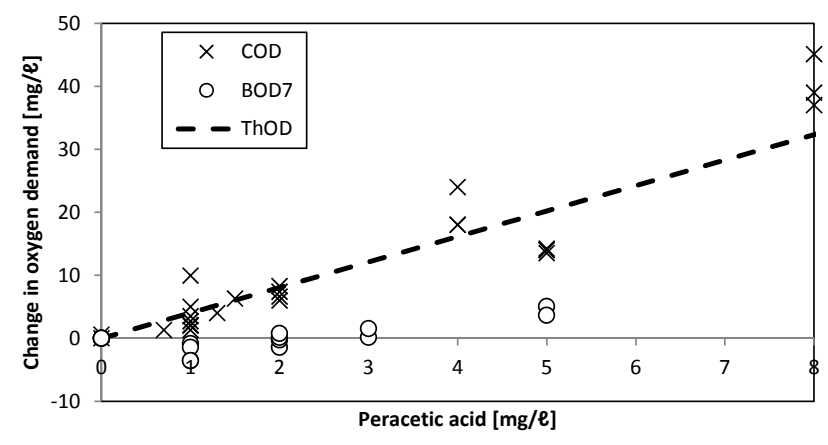

Figure 4

Changes in chemical $\left(C O D_{C}\right)$, biochemical $\left(B O D_{7, A T U}\right)$ and theoretical oxygen demand (ThOD) as a function of peracetic acid concentration.

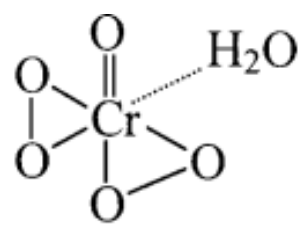

Figure 5

Structure of a chromium peroxide complex $\left(2 \mathrm{CrO}\left(\mathrm{O}_{2}\right)_{2} \cdot \mathrm{H}_{2} \mathrm{O}\right)$ formed by the reaction between hydrogen peroxide and dichromate ion in acidic conditions (Reaction 4).

(From: Grampp et al., 2002)

values than ThOD. This is possibly due to the interference caused by residual hydrogen peroxide (Talinli and Anderson, 1992). Several possible reactions have been reported in literature (Eqs. 4-7) explaining how hydrogen peroxide could react with the standard oxidising agent, the dichromate ion $\left(\mathrm{Cr}_{2} \mathrm{O}_{7}{ }^{2-}\right)$ (Talinli and Anderson, 1992). One such possible complex structure is shown in Fig. 5 (Grampp et al., 2002).

$$
\begin{aligned}
& \mathrm{Cr}_{2} \mathrm{O}_{7}^{2-}(\mathrm{aq})+4 \mathrm{H}_{2} \mathrm{O}_{2}(\mathrm{aq})+2 \mathrm{H}^{+}(\mathrm{aq}) \\
& \rightarrow 2 \mathrm{CrO}\left(\mathrm{O}_{2}\right)_{2} \cdot \mathrm{H}_{2} \mathrm{O}(\mathrm{aq})+4 \mathrm{H}_{2} \mathrm{O}(\mathrm{l}) \\
& \mathrm{Cr}_{2} \mathrm{O}_{7}{ }^{2-}(\mathrm{aq})+3 \mathrm{H}_{2} \mathrm{O}_{2}(\mathrm{aq})+8 \mathrm{H}^{+}(\mathrm{aq}) \\
& \rightarrow 2 \mathrm{Cr}^{3+}(\mathrm{aq})+3 \mathrm{O}_{2}(\mathrm{aq})+7 \mathrm{H}_{2} \mathrm{O}(\mathrm{l}) \\
& \mathrm{H}_{2} \mathrm{Cr}_{2} \mathrm{O}_{7}^{2-}(\mathrm{aq})+5 \mathrm{H}_{2} \mathrm{O}_{2}(\mathrm{aq}) \\
& \rightarrow \mathrm{H}_{2} \mathrm{Cr}_{2} \mathrm{O}_{12}(\mathrm{aq})+5 \mathrm{H}_{2} \mathrm{O}(\mathrm{l}) \\
& \mathrm{H}_{2} \mathrm{Cr}_{2} \mathrm{O}_{12}(\mathrm{aq})+8 \mathrm{H}_{2} \mathrm{O}_{2}(\mathrm{aq}) \\
& \rightarrow \mathrm{Cr}_{2} \mathrm{O}_{3}(\mathrm{aq})+9 \mathrm{H}_{2} \mathrm{O}(\mathrm{l})+8 \mathrm{O}_{2}(\mathrm{l})
\end{aligned}
$$

Reactions 4-7 can cause a positive error in the COD results. Talinli and Anderson (1992) pointed out that even water samples containing no organic compounds had COD values if they contained hydrogen peroxide. This topic was further studied by Kang et al. (1999) who proposed an empirical correction equation for the interference. Lee et al. (2011) discovered that $1 \mathrm{mg}$ of $\mathrm{H}_{2} \mathrm{O}_{2}$ caused an increase of 0.50 to $0.58 \mathrm{mg}$ of COD in anaerobically digested livestock wastewater. In a recent study, Wu and Englehardt (2012) proposed a chemical method for the removal of hydrogen peroxide interference. Their method employs addition of sodium carbonate and heating.

To the best of the authors' knowledge, the interference of hydrogen peroxide in the COD measurement has not been represented earlier in the context of PAA-based wastewater disinfection. This could be one of the reasons for the statement (e.g. Lazarova et al. (1998)) that PAA treatment substantially increases the organic load of the treated wastewater. However this is not the case if PAA is used in moderate doses. 


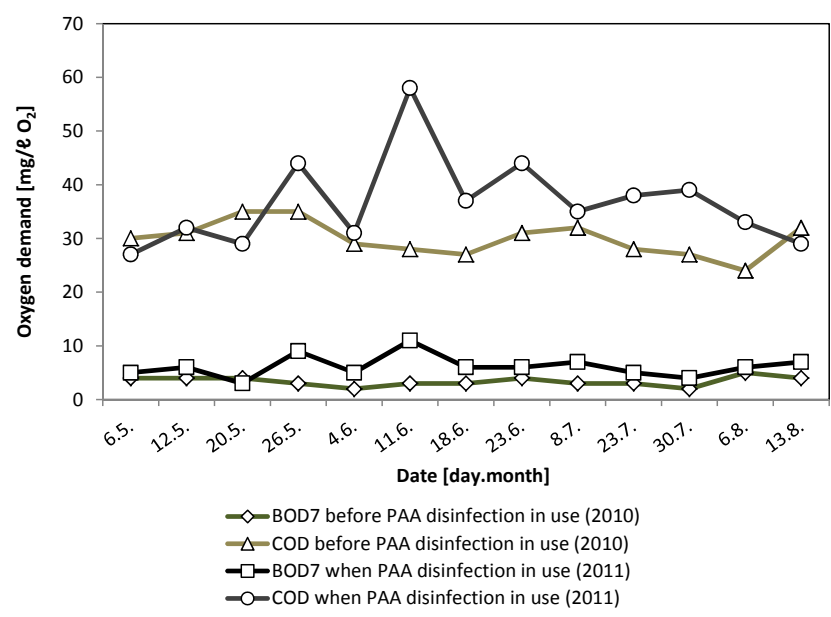

Figure 6

$B O D_{7 A T U}$ and COD Data from the Mikkeli Kenkävero wastewater treatment plant from 2010 (no PAA disinfection) and 2011 (PAA disinfection in use)

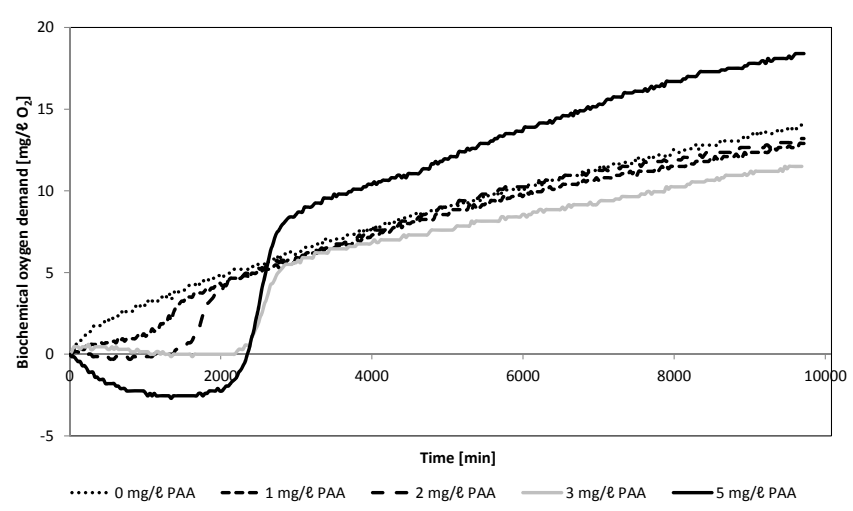

Figure 7

Biochemical oxygen demand as a function of time during measurement

Changes in BOD are well below those in ThOD and there seems to even be a slight decrease in BOD (BOD change being negative) in the concentration area of 1 to $2 \mathrm{mg} / \ell$ PAA. Interestingly Baldry et al. (1995) reported that the mean COD, as well as BOD, fell during the full-scale trial with PAA. In that case, the PAA dose was $5 \mathrm{mg} / \ell$ with a contact time of $10 \mathrm{~min}$. Their trial was performed at a WWTP which receives textile industry wastes in addition to domestic wastewater. A decrease in the mean COD and BOD could possibly be attributed to the oxidation of organics in the textile wastewater. For comparison, Fig. 6 shows data collected from Mikkeli Kenkävero WWTP in Finland which is using PAA disinfection for their final effluent. The data shows for the same period of time in consecutive years 2010 (no PAA disinfection) and 2011 (PAA disinfection in use) an average increase of $2.8 \mathrm{mg} / \ell \mathrm{O}_{2}$ for $\mathrm{BOD}_{7, \mathrm{ATU}}$. Some of this increase may be natural variation in the effluent quality.

Figure 7 shows changes of BOD during the measurement of $\mathrm{BOD}_{7}$ for tertiary effluent containing 0 to $5 \mathrm{mg} / \ell$ PAA. The method used (OxiTop) measures the change of gas pressure as biodegradation produced $\mathrm{CO}_{2}$ is absorbed by $\mathrm{NaOH}$ pellets. The initial negative $\mathrm{BOD}$ readings can be interpreted as a release of oxygen and subsequent increase of pressure. However after about 23 to $47 \mathrm{~h}$ this effect diminishes, depending on the PAA dose. It is also possible that PAA residual functions as a biocide and causes inhibition of biodegradation in the first $47 \mathrm{~h}$.

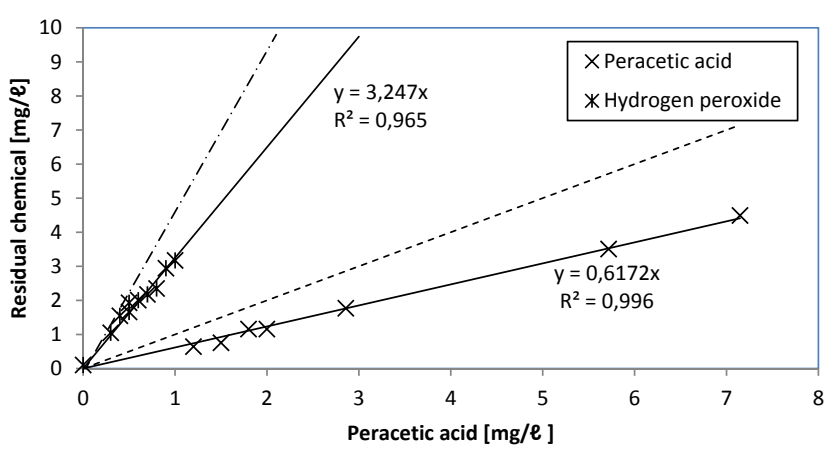

Figure 8

Residual PAA and hydrogen peroxide as a function of the dosed PAA after 1 min of contact time. The dashed lines refer to the zero consumption situations of PAA (lower) and hydrogen peroxide (upper), respectively.

However, it seems that biodegradation starts very quickly after residuals are consumed after $47 \mathrm{~h}$.

\section{Residual peracetic acid and hydrogen peroxide}

PAA-based wastewater disinfection usually leaves small residues of PAA and $\mathrm{H}_{2} \mathrm{O}_{2}$ in the effluent, as stated by, e.g., Veschetti et al. (2003). Typically, decomposition of PAA occurs in 2 phases: (i) initial, almost instantaneous decrease in concentration and (ii) subsequent slow decomposition of residual (Antonelli et al., 2006; Falsanisi et al., 2006). It is difficult to discriminate between factors affecting the initial decrease: e.g. particulates, reduced organic species, iron, manganese and micro-organisms have been shown to have effects (Falsanisi et al., 2006). Small amounts of PAA and hydrogen peroxide are, however, considered harmless to an aquatic environment and have been suggested to be beneficial in reducing the amounts of biofilms in effluent discharge pipes (Koivunen and HeinonenTanski., 2005b). Small residues of $\mathrm{H}_{2} \mathrm{O}_{2}$ are constantly present in water bodies as $\mathrm{H}_{2} \mathrm{O}_{2}$ is generated in the surface water layers by sunlight - initiated through photoredox reactions involving organic compounds (e.g. humic or fulvic acids), dissolved oxygen and trace metals (e.g. Fe or Mn) (Stumm and Morgan, 1996; Scully et al., 1995).

Results of PAA and $\mathrm{H}_{2} \mathrm{O}_{2}$ residual measurements after 1 min of contact time are presented in Fig. 8. Dashed lines represent zero consumption.

\section{Indicator microbes}

Amounts of male-specific $(\mathrm{F}+)$ and somatic coliphage viruses present in pre-treated (screening and sand removal) and tertiary effluents, together with disinfection results, are presented in Table 3. The process employed at the Taskila WWTP appeared to remove a substantial proportion of coliphage viruses, even without disinfection, during our test period (comparing pre-treated and tertiary effluent). Residual viruses are effectively removed with a dose of $1 \mathrm{mg} / \ell$ PAA and a contact time of $60 \mathrm{~min}$. However, there is a variation in disinfection results as dose is increased. This could be due to changes in the amount of coliphage viruses in the water to be disinfected.

Rajala-Mustonen et al. (1997) also studied the removal of coliphage virus with PAA but their doses were substantially higher. Mattle et al. (2011) reported that MS2 bacteriophage (an F-specific coliphage) was not inactivated by PAA in the absence of chloride. 


\begin{tabular}{|c|c|c|c|c|c|c|c|}
\hline \multicolumn{8}{|c|}{$\begin{array}{l}\text { TABLE } 3 \\
\text { Coliphage virus values obtained from the pilot-scale disinfection experiments }\end{array}$} \\
\hline \multirow{3}{*}{$\begin{array}{l}\text { PAA-dose } \\
(\mathrm{mg} / \mathrm{l})\end{array}$} & \multirow{3}{*}{$\begin{array}{l}\text { Contact } \\
\text { time (min) }\end{array}$} & \multirow{2}{*}{\multicolumn{3}{|c|}{$\begin{array}{c}\text { Somatic coliphages (PFU/100 m } \ell \text { ) } \\
\text { Pre-treated effluent* }\end{array}$}} & \multirow{2}{*}{\multicolumn{3}{|c|}{$\frac{\text { F-specific coliphages (PFU/100 m } \ell \text { ) }}{\text { Pre-treated effluent* }}$}} \\
\hline & & & & & & & \\
\hline & & Min. & Max. & Ave. & Min. & Max. & Ave. \\
\hline \multirow[t]{3}{*}{0} & - & 84700 & 6200000 & 3142400 & 112700 & 370000 & 241400 \\
\hline & & \multicolumn{3}{|c|}{ Tertiary effluent } & \multicolumn{3}{|c|}{ Tertiary effluent } \\
\hline & & Min. & Max. & Ave. & Min. & Max. & Ave. \\
\hline 0 & - & 170 & 4400 & 1800 & 40 & 800 & 420 \\
\hline 1 & 60 & 0 & 20 & 10 & 0 & 0 & 0 \\
\hline 4 & 60 & 0 & 0 & 0 & 0 & 0 & 0 \\
\hline 8 & 60 & 0 & 470 & 120 & 0 & 170 & 40 \\
\hline 12 & 60 & 30 & 30 & 30 & 30 & 30 & 30 \\
\hline
\end{tabular}

PFU = plaque forming unit

* $=$ involves screening and sand removal

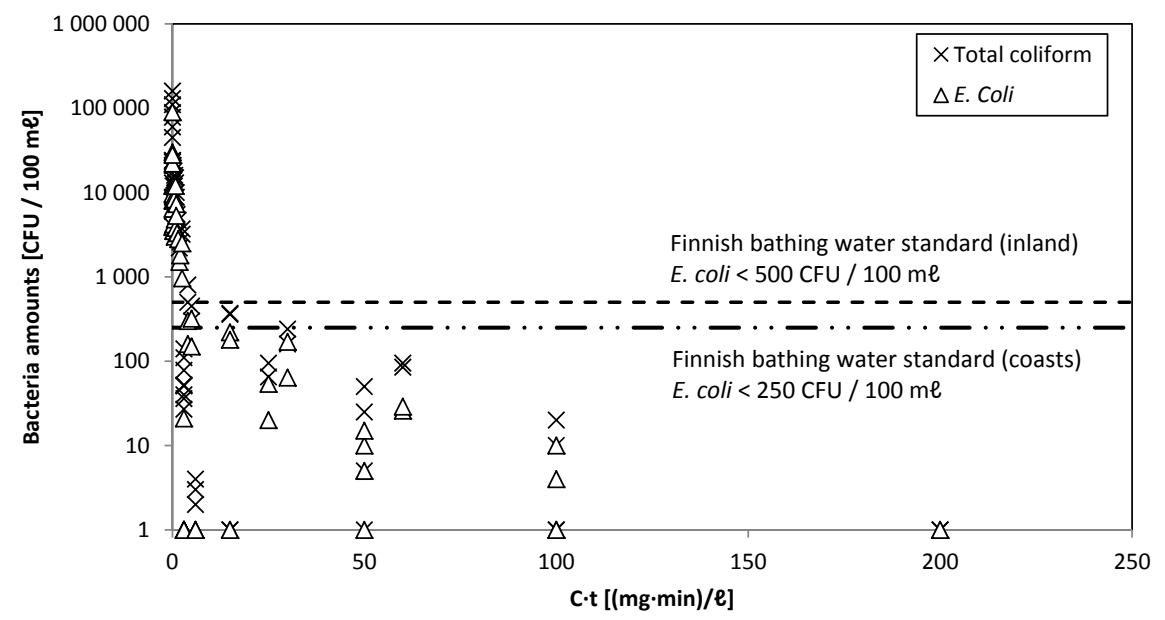

Figure 9

Total coliform bacteria and E. coli reductions in the pilotscale disinfection experiments
The amounts of TCB and E. coli on a logarithmic scale as a function of $C^{\star} t$ are shown in Fig. 9. The dashed lines in Fig. 9 illustrate the Finnish bathing water standards for inland and seashore areas (Ministry of Social Affairs and Health Decree 177/2008) which sets the quality requirements for monitoring of public bathing waters. Values below this standard indicate excellent bathing water quality. In terms of $E$. coli this means $<250 \mathrm{CFU} / 100 \mathrm{~m} \ell$ (coastal area) or $<500 \mathrm{CFU} / 100 \mathrm{~m} \ell$ (inland). In our experiments, these standards were achieved with a value of approx. 15 to 30 (mg.min)/ $/ \ell$ which equals to a dose of 1.5 to $2 \mathrm{mg} / \ell$ PAA and a contact time of 10 to $15 \mathrm{~min}$. In Finland there are no general requirements to disinfect wastewater effluents prior to discharge. However, if there are, e.g., bathing or recreational activities in the receiving water body, disinfection is demanded by the WWTP's individual environmental licence. As discharge waters are diluted in the receiving water body the required microbial quality is typically in the order of 2000 CFU/100 m $\ell$ for E. coli.

\section{CONCLUSIONS}

Our results demonstrate the effectiveness of PAA as a disinfectant using common indicator microbes E. coli, total coliforms and coliphage viruses. A dose of 1.5 to $2 \mathrm{mg} / \ell$ with a contact time of 10 to $15 \mathrm{~min}$ appears to be sufficient for bacteria removal from tertiary effluent and similar doses with a contact time of about $60 \mathrm{~min}$ for coliphage virus removal. However, there was variation in virus disinfection results at larger PAA doses.

We measured the following chemical parameters before and after PAA disinfection: $\mathrm{pH}, \mathrm{ORP}, \mathrm{COD}_{\mathrm{Cr}}, \mathrm{BOD}_{7, \mathrm{ATU}}$, and residual PAA and $\mathrm{H}_{2} \mathrm{O}_{2}$. There were negligible changes in the $\mathrm{pH}$ (about $0.5 \mathrm{pH}$ units), even at about $15 \mathrm{mg} / \ell$ of PAA, whilst ORP increased steeply within the concentration area of 0.1 to $1 \mathrm{mg} / \ell$. At concentrations greater than $1 \mathrm{mg} / \ell$ PAA the rate of increase diminishes. This is possibly due to a saturation of dissolved oxygen produced by the PAA and $\mathrm{H}_{2} \mathrm{O}_{2}$ decomposition. ORP was observed to correlate with residual bacterial amounts in the same way as reported in existing literature for chlorinebased disinfection. However, the correlation between residual bacterial amounts and residual PAA was found to be slightly better. $\mathrm{COD}_{\mathrm{Cr}}$ followed ThOD values closely but some measurements showed substantially larger COD than ThOD. This is due to the interference caused by hydrogen peroxide which is well documented in the literature. Finally, as residues of PAA may inhibit bacteria from decomposing organic material, $\mathrm{BOD}_{7 \text {, atu }}$ measurements may be inaccurate.

\section{ACKNOWLEDGEMENTS}

This study was partially funded by the Finnish Funding Agency for Technology and Innovation (TEKES) and PAC-Solution Ltd. The authors greatly appreciate these bodies' financial support. The authors would like to thank the whole staff of PAC-Solution Ltd and Oulun Vesi waterworks for valuable comments and co-operation during the study. The authors acknowledge the participation of Satu Hukkanen, Ville Kaikkonen, Lauri Parviainen, and Hanna Runtti for their assistance in conducting the tests and taking samples. 


\section{REFERENCES}

ANTONELLI M, ROSSI S, MEZZANOTTE V and NURIZZO C (2006) Secondary effluent disinfection: PAA long term efficiency. Environ. Sci. Technol. 40 (15) 4771-4775.

AZZELLINO A, ANTONELLI M, CANZIANI R, MALPEI F, MARINETTI M and NURIZZO C (2011) Multivariate modelling of disinfection kinetics: A comparison among three different disinfectants. Desalin. Water Treat. 29 (1-3) 128-139.

BALDRY MGC (1983) The bactericidal, fungicidal and sporicidal properties of hydrogen peroxide and peracetic acid. J. Appl. Bacteriol. 54 (3) 417-423

BALDRY MGC, CAVADORE A, FRENCH MS, MASSA G, RODRIGUES LM, SCHIRCH PFT and THREADGOLD TL (1995) Effluent disinfection in warm climates with peracetic acid. Water Sci. Technol. 31 (5-6) 161-164.

BALDRY MGC and FRENCH MS (1989) Disinfection of sewage effluent with peracetic acid. Water Sci. Technol. 21 (3) 203-206.

BALDRY MGC, FRENCH MS and SLATER D (1991) The activity of peracetic acid on sewage indicator bacteria and viruses. Water Sci. Technol. 24 (2) 353-357.

BERGENDAHL JA and STEVENS L (2005) Oxidation reduction potential as a measure of disinfection effectiveness for chlorination of wastewater. Environ. Prog. 24 (2) 214-222.

BIANCHINI R, CALUCCI L, LUBELLO C and PINZINO C (2002) Intermediate free radicals in the oxidation of wastewaters. Res. Chem. Intermed. 28 (2-3) 247-256.

BRIANCESCO R, VESCHETTI E, OTTAVIANI M and BONADONNA L (2005) Peracetic acid and sodium hypochlorite effectiveness in reducing resistant stages of microorganisms. Cent. Eur. J. Public Health 13 (3) 159-162.

CARETTI C and LUBELLO C (2003) Wastewater disinfection with PAA and UV combined treatment: A pilot plant study. Water Res. 37 (10) 2365-2371.

COLLIVIGNARELLI C, BERTANZA G and PEDRAZZANI R (2000) A comparison among different wastewater disinfection systems: Experimental results. Environ. Technol. 21 (1) 1-16.

CREBELLI R, CONTI L, MONARCA S, FERETTI D, ZERBINI I, ZANI C, VESCHETTI E, CUTILLI D and OTTAVIANI M (2005) Genotoxicity of the disinfection by-products resulting from peracetic acid- or hypochlorite-disinfected sewage wastewater. Water Res. 39 (6) 1105-1113.

DE VELÁSQUEZ MTO, YÁÑEZ-NOGUEZ I, JIMÉNEZ-CISNEROS B and LUNA PABELLO VM (2008) Adding silver and copper to hydrogen peroxide and peracetic acid in the disinfection of an advanced primary treatment effluent. Environ. Technol. 29 (11) 1209-1217.

DELL'ERBA A, FALSANISI D, LIBERTI L, NOTARNICOLA M and SANTORO D (2007) Disinfection by-products formation during wastewater disinfection with peracetic acid. Desalination 215 (1-3) 177-186.

DELL'ERBA A, FALSANISI D, LIBERTI L, NOTARNICOLA M and SANTORO D (2004) Disinfecting behaviour of peracetic acid for municipal wastewater reuse. Desalination 168 (1-3) 435-442.

FALSANISI D, GEHR R, SANTORO D, DELL'ERBA A, NOTARNICOLA M and LIBERTI L (2006) Kinetics of PAA demand and its implications on disinfection of wastewaters. Water. Qual. Res. J. Can. 41 (4) 398-409.

FRASER JAL, GODFREE AF and JONES F (1985) Use of peracetic acid in operational sewage sludge disposal to pasture. Water Sci. Technol. 17 (4-5 -5 pt 2) 451-466.

GEHR R, CHEN D and MOREAU M (2009) Performic acid (PFA): Tests on an advanced primary effluent show promising disinfection performance. Water Sci. Technol. 59 (1) 89-96.

GEHR R, WAGNER M, VEERASUBRAMANIAN P and PAYMENT P (2003) Disinfection efficiency of peracetic acid, UV and ozone after enhanced primary treatment of municipal wastewater. Water Res. 37 (19) 4573-4586.

GONCHARUK VV, BAGRII VA, MEL'NIK LA, CHEBOTAREVA RD and BASHTAN SY (2010) The use of redox potential in water treatment processes. J. Water Chem. Technol. 32 (1) 1-9.
GRAMPP G, LANDGRAF S, WESIERSKI T, JANKOWSKA B, KALISZ E, SABOU D and MLADENOVA B (2002) Kinetics of the formation of the blue complex $\mathrm{CrO}\left(\mathrm{O}_{2}\right)_{2}$ formed by dichromate and $\mathrm{H}_{2} \mathrm{O}_{2}$ in acid solutions. A stopped-flow investigation using rapidscan UV-VIS detection. Monatsh. Chem. 133 1363-1372.

GULTEKIN I and INCE NH (2004) Degradation of reactive azo dyes by UV/H2O2: Impact of radical scavengers. J. Environ. Sci. Health, Part A: Toxic/Hazard. Subst. Environ. Eng. 39 (4) 1069-1081.

KANG YW, CHO M and HWANG K (1999) Correction of hydrogen peroxide interference on standard chemical oxygen demand test. Water Res. 33 (5) 1247-1251.

KIM YH and HENSLEY R (1997) Effective control of chlorination and dechlorination at wastewater treatment plants using redox potential. Water Environ. Res. 69 (5) 1008-1014.

KITIS M (2004) Disinfection of wastewater with peracetic acid: A review. Environ Int. 30 (1) 47-55.

KOIVUNEN J and HEINONEN-TANSKI H (2005a) Inactivation of enteric microorganisms with chemical disinfectants, UV irradiation and combined chemical/UV treatments. Water Res. 39 (8) 1519-1526.

KOIVUNEN J and HEINONEN-TANSKI H (2005b) Peracetic acid (PAA) disinfection of primary, secondary and tertiary treated municipal wastewaters. Water Res. 39 (18) 4445-4453.

LAZAROVA V, JANEX ML, FIKSDAL L, OBERG C, BARCINA I and POMMEPUY M (1998) Advanced wastewater disinfection technologies: Short and long term efficiency. Water Sci. Technol. 38 (12) 109-117.

LEE E, LEE H, KIM YK, SOHN K and LEE K (2011) Hydrogen peroxide interference in chemical oxygen demand during ozone based advanced oxidation of anaerobically digested livestock wastewater. Int. J. Environ. Sci. Technol. 8 (2) 381-388.

LEFEVRE F, AUDIC JM and FERRAND F (1992) Peracetic acid disinfection of secondary effluents discharged off coastal seawater. Water Sci. Technol. 25 (12) 155-164.

LIAO C, KANG S and WU F (2001) Hydroxyl radical scavenging role of chloride and bicarbonate ions in the $\mathrm{H}_{2} \mathrm{O}_{2} / \mathrm{UV}$ process. Chemosphere 44 (5) 1193-1200.

LIBERTI L, LOPEZ A and NOTARNICOLA M (1999) Disinfection with peracetic acid for domestic sewage re-use in agriculture. $J$. Chart. Inst. Water Environ. Manage. 13 (4) 262-269.

LIBERTI L and NOTARNICOLA M (1999) Advanced treatment and disinfection for municipal wastewater reuse in agriculture. Water Sci. Technol. 40 (4-5) 235-245.

LUBELLO C, CARETTI C and GORI R (2002) Comparison between $\mathrm{PAA} / \mathrm{UV}$ and $\mathrm{H} 2 \mathrm{O} 2 / \mathrm{UV}$ disinfection for wastewater reuse. Water Sci. Technol.: Water Supply 2 (1) 205-212.

LUNA-PABELLO VM, RÍOS MM, JIMÉNEZ B and ORTA DE VELASQUEZ MT (2009) Effectiveness of the use of Ag, Cu and PAA to disinfect municipal wastewater. Environ. Technol. 30 (2) 129-139.

MATTLE MJ, CROUZY B, BRENNECKE M, R. WIGGINTON K, PERONA P and KOHN T (2011) Impact of virus aggregation on inactivation by peracetic acid and implications for other disinfectants. Environ. Sci. Technol. 45 (18) 7710-7717.

MEZZANOTTE V, ANTONELLI M, CITTERIO S and NURIZZO C (2007) Wastewater disinfection alternatives: Chlorine, ozone, peracetic acid, and UV light. Water Environ. Res. 79 (12) 2373-2379.

MONARCA S, RICHARDSON SD, FERETTI D, GROTTOLO M, THRUSTON JR. AD, ZANI C, NAVAZIO G, RAGAZZO P, ZERBINI I and ALBERTI A (2002) Mutagenicity and disinfection by-products in surface drinking water disinfected with peracetic acid. Environ. Toxicol. Chem. 21 (2) 309-318.

ORTH R (1998) The importance of disinfection for the hygiene in the dairy and beverage production. Int. Biodeterior. Biodegrad. 41 (3-4) 201-208.

RAJALA-MUSTONEN RL, TOIVOLA PS and HEINONEN-TANSKI $\mathrm{H}$ (1997) Effects of peracetic acid and UV irradiation on the inactivation of coliphages in wastewater. Water Sci. Technol. 35 (11-12) 237-241.

RASIMUS S, KOLARI M, RITA H, HOORNSTRA D and SALKINOJA-SALONEN M (2011) Biofilm-forming bacteria with varying tolerance to peracetic acid from a paper machine. J. Ind. 
Microbiol. Biotechnol. 38 (9) 1379-1390.

ROTHBART S, EMBER EE and VAN ELDIK R (2012) Mechanistic studies on the oxidative degradation of Orange II by peracetic acid catalyzed by simple manganese(II) salts. Tuning the lifetime of the catalyst. New J. Chem. 36 (3) 732-748.

ROZEN Y and BELKIN S (2001) Survival of enteric bacteria in seawater. FEMS Microbiol. Rev. 25 (5) 513-529.

SALGOT M, FOLCH M, HUERTAS E, TAPIAS J, AVELLANEDA D, GIRÓS G, BRISSAUD F, VERGÉS C, MOLINA J and PIGEM J (2002) Comparison of different advanced disinfection systems for wastewater reclamation. Water Sci. Technol.: Water Supply 2 (3) 213-218.

SCULLY NM, LEAN DRS, MCQUEEN DJ and COOPER WJ (1995) Photochemical formation of hydrogen peroxide in lakes: effects of dissolved organic carbon and ultraviolet radiation. Can. J. Fish. Aquat. Sci. 52 (12) 2675-2681.

STAMPI S, DE LUCA G and ZANETTI F (2001) Evaluation of the efficiency of peracetic acid in the disinfection of sewage effluents. J. Appl. Microbiol. 91 (5) 833-838.

STUMM W and MORGAN JJ (1996) Aquatic Chemistry, Chemical Equilibria and Rates in Natural Waters. John Wiley \& Sons, New York. 1022 pp.
TALINLI I and ANDERSON GK (1992) Interference of hydrogen peroxide on the standard COD test. Water Res. 26 (1) 107-110.

TCHOBANOGLOUS G, BURTON FL and STENSEL HD (2004) Wastewater Engineering Treatment and Reuse. Mc Graw Hill, New York. 1819 pp.

VESCHETTI E, CUTILLI D, BONADONNA L, BRIANCESCO R, MARTINI C, CECCHINI G, ANASTASI P and OTTAVIANI M (2003) Pilot-plant comparative study of peracetic acid and sodium hypochlorite wastewater disinfection. Water Res. 37 (1) 78-94.

WU T and ENGLEHARDT JD (2012) A new method for removal of hydrogen peroxide interference in the analysis of chemical oxygen demand. Environmental Sci. Technol. 46 (4) 2291-2298.

YU RF and CHENG WP (2003) Determination of chlorine demand in water and wastewater chlorination by oxidation-reduction potential. Water Sci. Technol.: Water Supply 3 (1-2) 313-320.

ZANETTI F, DE LUCA G, SACCHETTI R and STAMPI S (2007) Disinfection efficiency of peracetic acid (PAA): Inactivation of coliphages and bacterial indicators in a municipal wastewater plant. Environ. Technol. 28 (11) 1265-1271.

ZHAO X, CHENG K, HAO J and LIU D (2008) Preparation of peracetic acid from hydrogen peroxide, part II: Kinetics for spontaneous decomposition of peracetic acid in the liquid phase. J. Mol. Catal. A: Chem. 284 (1-2) 58-68. 